Article

\title{
Extraseasonal Production in a Soilless System and Characterisation of Landraces of Carosello and Barattiere (Cucumis melo L.)
}

\author{
Annalisa Somma ${ }^{1}\left(\mathbb{D}\right.$, Onofrio Davide Palmitessa ${ }^{1, *(D)}$, Beniamino Leoni ${ }^{1}$, Angelo Signore ${ }^{1}(\mathbb{D}$, \\ Massimiliano Renna ${ }^{1,2}$ (D) and Pietro Santamaria ${ }^{1}$ (D)
}

1 Department of Agricultural and Environmental Science, University of Bari Aldo Moro, Via Amendola 165/a, 70126 Bari, Italy; annalisa.somma@uniba.it (A.S.); beniamino.leoni@uniba.it (B.L.); angelo.signore@uniba.it (A.S.); massimiliano.renna@ispa.cnr.it (M.R.); pietro.santamaria@uniba.it (P.S.)

2 Institute of Sciences of Food Production, National Research Council of Italy, 70126 Bari, Italy

* Correspondence: onofrio.palmitessa@uniba.it

Citation: Somma, A.; Palmitessa, O.D.; Leoni, B.; Signore, A.; Renna, M.; Santamaria, P. Extraseasonal Production in a Soilless System and Characterisation of Landraces of Carosello and Barattiere (Cucumis melo L.). Sustainability 2021, 13, 11425. https://doi.org/10.3390/su132011425

Academic Editor: Michael S. Carolan

Received: 16 September 2021

Accepted: 12 October 2021

Published: 15 October 2021

Publisher's Note: MDPI stays neutral with regard to jurisdictional claims in published maps and institutional affiliations.

Copyright: (c) 2021 by the authors. Licensee MDPI, Basel, Switzerland. This article is an open access article distributed under the terms and conditions of the Creative Commons Attribution (CC BY) license (https:// creativecommons.org/licenses/by/ $4.0 /)$.

\begin{abstract}
Barattiere and Carosello are typical melon (Cucumis melo L.) landraces of Puglia's (Southern Italy) biodiversity. Their unripe fruits are locally consumed as an alternative to cucumbers (C. sativus L.) and are appreciated for their qualitative profile. Nevertheless, they are underutilized crops. For the high variability and confusing denominations, a morphological characterization is essential to discriminate and valorise landraces; additionally, it is fundamental to implement the agronomic technique to allow the cultivation outside the natural growth period (summer) by soilless cultivation. Two genotypes of Barattiere ('Allungato' and 'Tondo'), two of Carosello ('Scopatizzo' and 'Tomentoso' (CAT)) and two of cucumber ('Baby Star' and 'Modan' hybrids) were vertically grown in the winter-spring period in a rockwool soilless system in a glasshouse with supplemental light. Landraces were characterized by morpho-physiological descriptors of melon; fruit biometrics and colour were analysed for all genotypes; productive parameters, leaf fluorescence, and chlorophyll content were measured. Genotypes varied in seeds, stem, leaf, fruit traits and they were andromonoecious; Carosello flowered earlier and produced more than Barattiere; CAT fruits were hairy and elongate, while other genotypes tended to rounder and glabrous fruits. Although landraces grew slower than cucumbers, both produced marketable fruits and the production of Carosello was comparable to cucumbers. In conclusion, Barattiere and Carosello have a productive potential and one vertically trained stem in a soilless system is appropriate for their extra-seasonal production.
\end{abstract}

Keywords: agrobiodiversity; morphological descriptors; unripe melons; C. sativus L.

\section{Introduction}

Landraces and ecotypes are a remarkable source to improve human health and nutrition. However, most of them are neglected and poorly known. Puglia region, in Southern Italy, boasts a rich and varied panorama of landraces and local vegetables, which are traditionally grown and consumed for their nutritive and beneficial properties [1]. Despite the traditional knowledge and current use, the awareness of their value and the potential role as a crop for human consumption are still underestimated [2-5]. One of the most representative examples of Apulian vegetable biodiversity is the species Cucumis melo L. (melon) of the Cucurbitaceae family. The current richness in C. melo populations is due to Puglia's role as an important secondary centre of diversity for melons [6]. Two of the most appreciated Apulian vegetables are the melon landraces 'Carosello' and 'Barattiere'.

Although Carosello and Barattiere are taxonomically melons, their fruits are harvested at the immature stage to be consumed fresh and raw, in salads or without dressings [1]. They have a tendentially green peel and differ in shape (from cylindrical to rounded) and in pubescence (abundant, reduced, or absent). For their appearance and culinary preparation, 
Carosello and Barattiere are often erroneously considered cucumbers and are traditionally consumed as an alternative to cucumbers (Cucumis sativus L.). The fruits are usually harvested when the flesh is firm and crunchy, seeds are immature and inconsistent, and the placenta cavity is absent; consequently, the whole fruit can be consumed [1]. Moreover, the whole immature and soft placenta can be eaten at this stage and the local people have named it "green caviar" [7]. They are appreciated not only for the absence of a bitter taste and their refreshing and organoleptic properties but also for their digestibility and nutritional value $[1,8,9]$. Previous studies indicate that the quality profile of Carosello and Barattiere is valuable and higher than cucumber: for example, Serio et al. (2005) reported that they have high potassium and low reducing sugar and sodium contents [10]. Nevertheless, these unripe melons are mainly appreciated and promoted at a local level and can be considered underutilized crops [7,11]. Despite the poor and unofficial data on cultivation distribution of Carosello and Barattiere, they are grown in different regions of the South of Italy, both in open fields and greenhouses, and attempts to export the product have already been promoted [7].

Due to the high intraspecific variability in Apulian melons, the genetic and taxonomic characterization of Carosello and Barattiere have been updated over the decades [12-14]. In 2017, a molecular study defined Carosello as part of a subpopulation of a C. melo subsp. agrestis group Chate, while Barattiere was assigned to a different subpopulation [6], unlike previous classification [13]. Chate melon cultivation has a very ancient origin and its consumption was popular in the past, unlike the current local distribution [15-18].

Being landraces, Carosello and Barattiere show a high variability that is exhibited at the phenotypic level, which is particularly evident in fruit morphology. Consequently, different and overlapping names are attributed to numerous local varieties usually in relation to the areas of cultivation and fruit features $[1,8,13]$. In addition, poor and empiric selection has been applied and seeds are collected by farmers or local nurseries without guarantee of variety identity. In recent years, the efforts to preserve regional germplasm, registration in the national catalogue, and genetic studies on local populations [3] contributed to the knowledge of many local genotypes.

A complementary approach to the preservation and promotion of local vegetables is the growth of commercial purposes and the awareness of their nutritional properties. Carosello and Barattiere are adapted to the Mediterranean areas and naturally grow in the summer season. The application of appropriate agricultural practices, soilless cultivation systems, and technologies are able to increase the production and the quality of fruits and also the availability throughout the year $[1,7,9,10,19-22]$. Deep knowledge of plant morphology (shape, size, superficial patterns, hairiness, spatial arrangement of organs) and sex expression (sex of reproductive organs and their combinations in the flower and on the plant) are also fundamental for this purpose: the former to implement an appropriate training system, the latter to set adequate cultural techniques, like pruning, in order to maximize the plant productive potential. Landraces can also be valorised for further useful agronomical features in melon breeding, for example as potential sources for pathogen resistance [23] and organoleptic and nutritional traits [24-26].

All considered, the discrimination of different populations on the basis of visual traits of plants and the knowledge of the sexual expression and reproductive habitus are essential for the valorisation of local varieties and the optimisation of agronomic techniques and production. Therefore, description and characterization of local varieties/populations are a key step towards the protection, valorisation, and promotion of Carosello and Barattiere.

Following the reported needs for valorisation of the abovementioned landraces of C. melo, this study focused on four landraces of C. melo, two of Carosello and two of Barattiere, which are commonly subjected to identification mistakes, with the following aims: describe and characterize their morphology and to compare their productive potential to commercial hybrids of cucumber (C. sativus), in a rockwool soilless system with supplementary LED lamps with vertically trained plants. 


\section{Materials and Methods}

\subsection{Experimental Location}

The experiment was carried out between January and May 2021 (winter-spring) at the commercial soilless farm "F.lli Lapietra" located in Monopoli (BA, Southern Italy, $40.90287126353^{\circ} \mathrm{N}, 17.3277492^{\circ} \mathrm{E}$ ) in a heated semi-closed glasshouse provided with supplementary light by toplight LED lamps and roof glasses with $96.5 \%$ of light transmission measured with the Normal (NEN 2675) method.

\subsection{Plant Material and Growing Conditions}

Four landraces of unripe melon (Cucumis melo L.) and two commercial F1 hybrids of cucumber (Cucumis sativus L.) were tested: two genotypes of Barattiere ('Allungato' (BA) and 'Tondo' (BT)); two genotypes of Carosello ('Scopatizzo' (CAS) and 'Tomentoso' (CAT)); two genotypes of cucumber ('Baby Star' (CB) and 'Modan' (CS) (Rijk Zwaan)). The fruits of Carosello and Barattiere are common in local markets (Figure 1) and mainly differ in shape and pubescence: CAT is approximately cylindrical and with dense hair; CAS, BA, and BT are tendentially rounded and with reduced or absent pubescence. Seeds were sown on 21 January 2021 in rockwool cubes (Grodan, $10 \times 10 \times 6.5 \mathrm{~cm}$ ) in the plant nursery of the farm, and cubes with two plants each were transplanted on 16 February 2021 at the three true leaves stage in rockwool slabs in the greenhouse with a distance between plants of $33.3 \mathrm{~cm}$ $\left(3.2 \mathrm{stems} \cdot \mathrm{m}^{-2}\right)$. The principal stems of BA and BT were tipped above the second node seven days after transplanting (DAT), according to the traditional growing practice [9], and one primary stem of each plant was grown until the height of $3 \mathrm{~m}$, after which they were topped. The principal stem was grown for the other genotypes. The grown stems were trained vertically and the lateral stems were tipped after the second node [7]. Periodic operations of binding and basal leaf pruning were carried out. Pollination was guaranteed by the arrangement of bumblebee (Bombus terrestris L.) hives into the greenhouse, while pest management was carried out according to biological control strategies. The growing cycle lasted 14 weeks from the transplant.

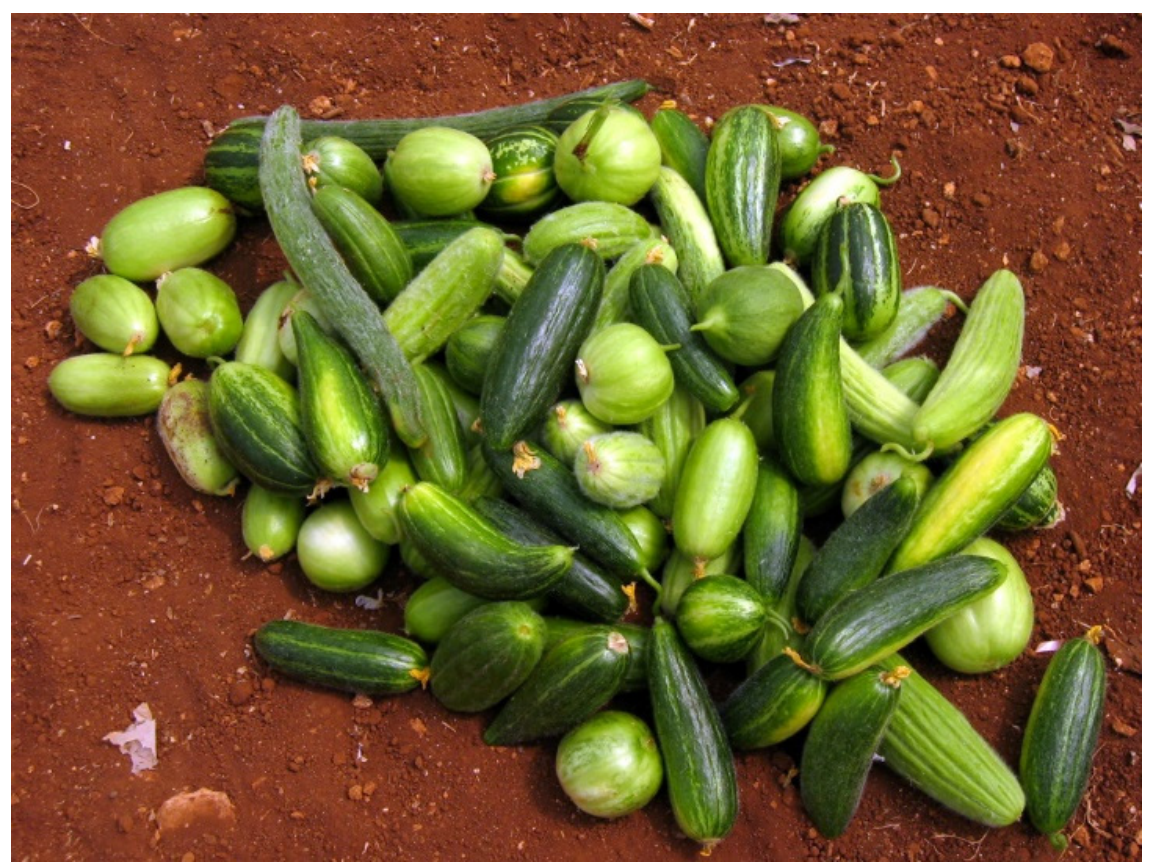

Figure 1. Mix of fruits of Carosello and Barattiere landraces of Puglia region at commercial maturity stage.

The closed-cycle management of nutrient solution (NS) was adopted and a fertirrigation schedule was set to avoid water stress and the number of irrigation events was 
adjusted during the growing cycle. Electrical conductivity (EC) and $\mathrm{pH}$ were measured before and after each NS recycle to guarantee a constant value of $2.5-3.0 \mathrm{mS} \cdot \mathrm{cm}^{-1}$ and $5.5-5.7$, respectively. NS was delivered by an automated drip system with a flow rate of $4 \mathrm{~L} \cdot \mathrm{h}^{-1}$ and it was composed of $18 \mathrm{mg} \cdot \mathrm{L}^{-1} \mathrm{~N}-\mathrm{NH}_{4}, 224 \mathrm{mg} \cdot \mathrm{L}^{-1} \mathrm{~N}-\mathrm{NO}_{3}, 39 \mathrm{mg} \cdot \mathrm{L}^{-1} \mathrm{P}, 313 \mathrm{mg} \cdot \mathrm{L}^{-1} \mathrm{~K}$, $160 \mathrm{mg} \cdot \mathrm{L}^{-1} \mathrm{Ca}, 44 \mathrm{mg} \cdot \mathrm{L}^{-1} \mathrm{~S}$, and $33 \mathrm{mg} \cdot \mathrm{L}^{-1} \mathrm{Mg}$; micronutrient concentrations were in accordance with Hoagland and Arnon [27].

\subsection{Supplemental Light}

Supplemental light started from the day of transplanting and continued until the end of the crop cycle. It was provided by GreenPower LED Toplight version 1.2 Deep Red/White/Low Blue High Output (Signify, Eindhoven, The Netherlands), with a spectral quality composition by $88 \%$ deep red $(650 \mathrm{~nm}), 5 \%$ green $(530 \mathrm{~nm})$, and $7 \%$ low blue $(460 \mathrm{~nm})$. Fixtures were installed above each plant at a fixed height; referring to fully grown and topped plants $(3 \mathrm{~m})$, the distance between the plant top and the lamps was $1.70 \mathrm{~m}$ and the average photosynthetic photon flux density (PPFD) emitted from the LEDs was $175 \mathrm{~mol} \cdot \mathrm{m}^{-2} \cdot \mathrm{d}^{-1}$ at the top of the plants. The photoperiod was fixed at $12 \mathrm{~h}$ and the lamps management was automated. DLI of natural light in the glasshouse was $30.6 \pm 1.6 \mathrm{~mol} \cdot \mathrm{m}^{-2} \cdot \mathrm{d}^{-1}$. To measure PPFD and DLI in the glasshouse, a quantum sensor (LI-191SA, LI-COR Biosciences, Superior Street Lincoln, NE, USA) was placed at the height of the plants' heads.

\subsection{Morpho-Physiological Descriptors}

Landraces of C. melo were described according to the descriptor model of GIBA (Gruppo di Lavoro Nazionale sulla Biodiversità Agraria, i.e., the Italian term for "National Working Group on Agricultural Biodiversity") for melon (Rif. CPVO TP/104/2) [28]. The model was integrated with further morphological descriptors of the International Plant Genetic Resources Institute (IPGRI) [29], Pandey et al. [30], and further literature on the Cucurbitaceae Family and genus Cucumis [31,32]. The following organs and plant developmental stages were considered: seed, seedling, cotyledonary leaf, flowering plant, true leaf, stem of various order, inflorescence, young, and harvested fruits. Floral examination and pubescence observations were supported by dissecting microscope and macro photography. ImageJ software [33] was used to measure the values of the numerical descriptors. A different number of repeated observations was taken according to model requirements and sample availability.

\subsection{Biometrics and Fruit Yield}

The harvest started between March and April depending on the genotype. Fruits were harvested three times a week and in accordance with the parameters defining the commercial maturity stage and the typical form and size of the fruits in local markets: CAT'S fruits were harvested when the grooves of fruit exocarp (rind or skin) were superficial, CAS, BA, BT fruits when the placenta cavity was absent and fruit weight was approximately 200-350 g $[1,8]$.

The biometric characteristics of the harvested fruits were measured for all the genotypes as a complement of morphological fruit descriptors: equatorial diameter (diameter of the maximum traverse section of the fruit); polar diameter (diameter of traverse section distant approximately $1 \mathrm{~cm}$ from the peduncular extremity); fruit length (axial distance from peduncular to pistillar extremities); mesocarp (flesh) thickness; endosperm (placenta) length and width (Figure 2).

The following productive measurements were taken: number of fruits produced by each plant, yield weight of genotype, and fresh weight (FW) and dry weight (DW) of fruits. Dry weight was measured on fresh samples (pieces of fruits) stored in a drying oven at $70{ }^{\circ} \mathrm{C}$ until a constant weight was measured. 


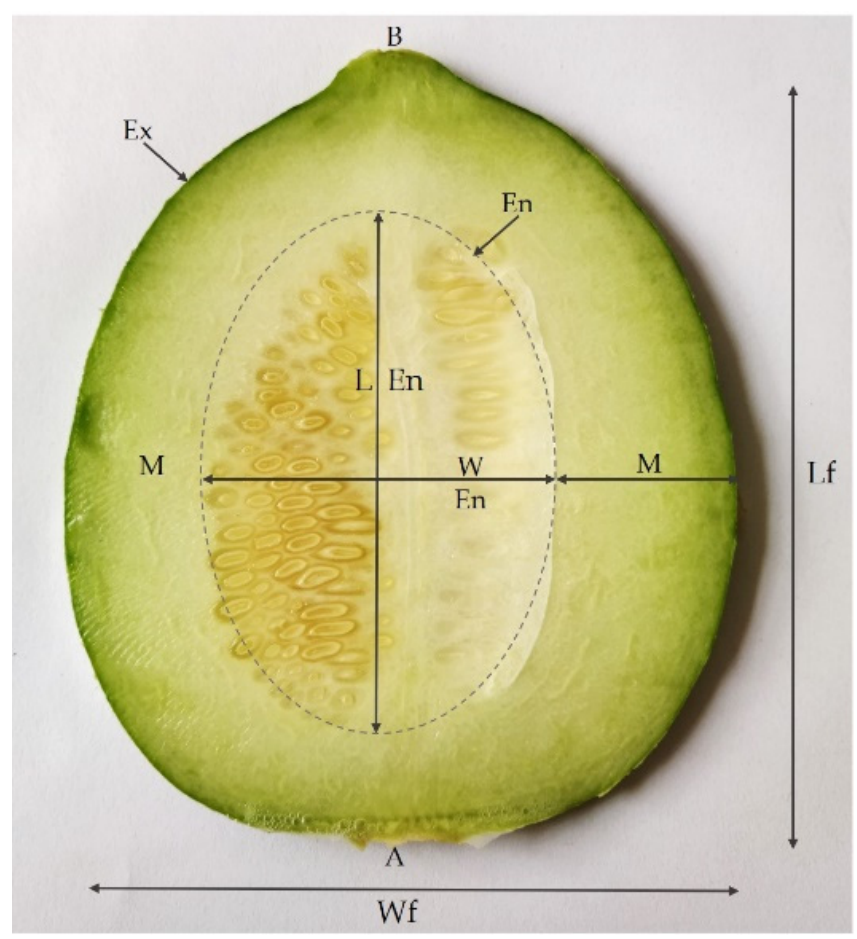

Figure 2. Illustration of biometric parameters on longitudinal section of Barattiere fruit: A, apex or pistillar extremity or blossom end; B, base or peduncular extremity or stem end; Ex, exocarp or skin; En, endocarp or placenta; f, fruit; LEn, length of endocarp; Lf, length of fruit; M, mesocarp or flesh; WEn, width of endocarp; Wf, width of fruit.

\subsection{Colour Analysis of Fruits}

Exocarp and mesocarp colours were analysed on freshly cut fruit by a portable colorimeter (Minolta Chroma Meter CR-400; Minolta Camera Co. Ltd., Osaka, Japan) and the result was expressed by the CIELAB colour scale $\left(\mathrm{L}, \mathrm{a}^{*}, \mathrm{~b}^{*}\right)$, which refers to three coordinates: $\mathrm{L}$, "lightness" (values from black $=0$ to white $=1$ ); $\mathrm{a}^{*}$, "red / green chromaticity or redness" (positive values tend to red, negative values tend to green); $b^{*}$, "yellow/blue chromaticity or yellowness"(positive values tend to yellow, negative values tend to blue). From this analysis other colour parameters were calculated: Hue angle $\left(h^{\circ}=\tan ^{-1} b^{*} / a^{*}\right)$, pointing the dominant colour; colour saturation or chroma $\left(C=\left[\left(a^{*}\right)^{2}+\left(b^{*}\right)^{2}\right]^{1 / 2}\right)$, representing the brightness. The colorimeter was calibrated with a standard reference having $\mathrm{L}^{*}, \mathrm{a}^{*}$, and $b^{*}$ values of 104.6, 0.07, and 2.1 respectively. Five internal and external measurements of colour were taken for fruit and three fruits for each treatment were considered. Colour analysis was repeated once a week during the harvest period.

\subsection{Crop Registration and Chlorophyll Parameters}

Starting from $22 \mathrm{DAT}$, the following crop parameters were measured: weekly increase of grown stem length, number of leaves on the grown stem, average internode length in the last week of the crop cycle, average petiole length of fully expanded leaves, number of harvested fruits.

The chlorophyll content of each plant was measured by an Apogee chlorophyll meter (MC-100, LI-COR instrument) on fully expanded leaves.

The chlorophyll fluorescence parameters of $\mathrm{F}^{\prime}$ (ground fluorescence in the lightadapted state), Fm' (maximum fluorescence level induced by a saturation light pulse), ФPSII (quantum yield of photosystem II), non-photochemical quenching (NPQ), qP (photochemical quenching), Fv/Fm (maximum photochemical quantum yield of PS II) were measured by a portable fluorometer (Pam-2500, WALZ, Rohrdorf, Germany) [34] on fully expanded leaves of each plant after a dark adaptation of at least $30 \mathrm{~min}$. 


\subsection{Experimental Design and Statistical Analysis}

The experimental design was a randomized block with three repetitions disposed on the same direction line. The layout consisted of three rockwool slabs, in which blocks of six plants for each genotype were randomly disposed of in a row; the block was represented by three couples of plants spaced $33.3 \mathrm{~cm}$ apart. All data underwent analysis of variance (ANOVA) using the General Linear model (GLM; SAS Software, Cary, NC, USA). The experimental factors were fixed by one-way analysis of variance (ANOVA), except for colour that was analysed by two-way ANOVA. Orthogonal contrasts technique was used to establish differences between means (five contrasts): (1) cucumbers (CS and CB) vs. others (CAS, CAT, BA, BT); (2) Barattiere (BA and BT) vs. Carosello (CAS and CAT); (3) cucumbers (CB vs. CS); (4) Carosello (CAS vs. CAT); (5) Barattiere (BA vs. BT).

\section{Results and Discussion}

\subsection{Morpho-Physiological Descriptors}

Landraces of Carosello and Barattiere are characterized by a considerable intraspecific variability at the phenotypic level, which was confirmed by the application of morphophysiological descriptors to the tested genotypes [8]. Considering that they belong to the same species, the botanic characters were shared between genotypes [31], whereas the main differences were detected in relation to the shape, size, colour, and pubescence of the examined organs (Table 1).

Seeds were produced in high numbers $(>100)$ from each fruit and they show high similarity in shape and surface appearance. However, the Carosello seeds were slightly smaller than the Barattiere ones and the genotypes differed in the colour of the external tegument.

Seedling showed a high level of resemblance in colour, size, shape, and bitterness (Table 1).

The tested genotypes exhibited an indeterminate plant growth habit and herbaceous stems (vines) supported by simple tendrils, singularly growing from each node. The first internodes of the CAT's principal stem were shorter $(<5 \mathrm{~cm})$ than the intermediate (approximately $10 \mathrm{~cm}$ ) internodes of the same stem and of the other genotypes' principal stem; they formed a fruitful basal rosette (Figure 3).

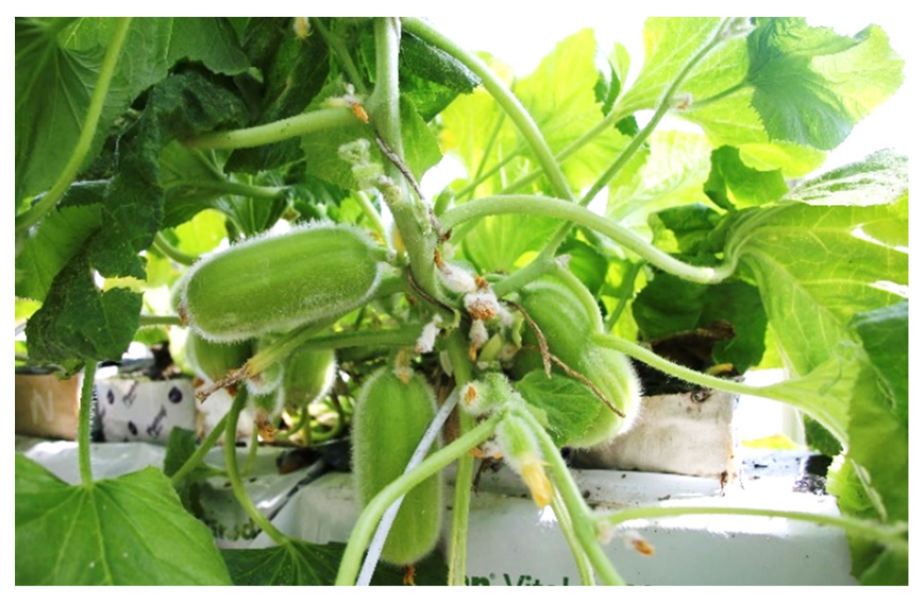

(a)

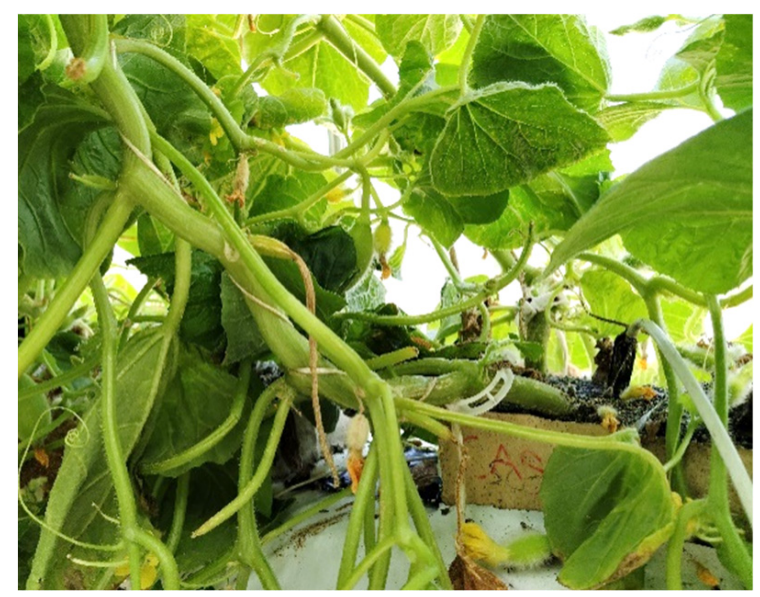

(b)

Figure 3. Different length of basal internodes of the principal stem of the Carosello 'Tomentoso' (CAT) compared to the principal stem of the other local genotypes: (a) CAT, short first internodes (basal rosette) bearing fruits; (b) Carosello 'Scopatizzo' (CAS), first internodes of intermediate length and not bearing fruits. 


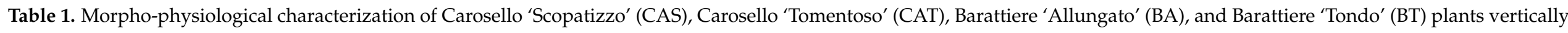

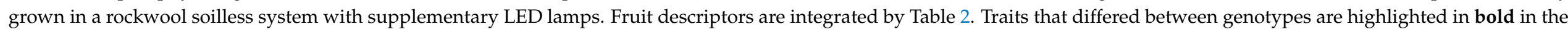
"Descriptor" column. Descriptors adapted from UPOV [28] and IPGR [29]. Dash symbolizes not available data.

\begin{tabular}{|c|c|c|c|c|c|}
\hline Part of Plant & Descriptor & CAS & CAT & BA & BT \\
\hline \multirow{7}{*}{ SEED $^{1}$} & Shape & Pine-nut shape, elliptic cross section & Pine-nut shape, elliptic cross section & Pine-nut shape, elliptic cross section & Pine-nut shape, elliptic cross section \\
\hline & Length & Short & Short & Medium & Medium \\
\hline & Width & Narrow & Narrow & Narrow & Narrow \\
\hline & Coat colour, colour intensity & Cream yellow, light-medium & Whitish & Cream yellow, light & Cream yellow, light \\
\hline & Coat surface & Smooth & Smooth & Smooth & Smooth \\
\hline & Coat pattern & Absent & Absent & Absent & Absent \\
\hline & Number of seeds.fruit ${ }^{-1}$ & High $(>100)$ & $\operatorname{High}(>100)$ & High $(>100)$ & High $(>100)$ \\
\hline \multirow{4}{*}{ SEEDLING } & Epicotyl colour & Light green & Light green & Light green & Light green \\
\hline & Hypocotyl colour & Light green & Light green & Light green & Light green \\
\hline & Hypocotyl pubescence & Present (velvety) & Present (velvety) & Present (velvety) & Present (velvety) \\
\hline & Cotyledon size & Medium & Medium & Medium & Medium \\
\hline \multirow{9}{*}{ STEM $^{2}$} & Plant growth habit & \multirow{5}{*}{$\begin{array}{c}\text { Indeterminate } \\
\text { Absent } \\
\text { Intermediate } \\
\text { Light green } \\
\text { Shallow longitudinal and parallel } \\
\text { grooves }\end{array}$} & \multirow{5}{*}{$\begin{array}{c}\text { Indeterminate } \\
\text { Present } \\
\text { Intermediate } \\
\text { Light green } \\
\text { Shallow longitudinal and parallel } \\
\text { grooves }\end{array}$} & Indeterminate & Indeterminate \\
\hline & Basal rosette & & & Absent & Absent \\
\hline & Internode length $^{3}$ & & & Intermediate & Intermediate \\
\hline & Primary colour & & & Light green & Light green \\
\hline & Stem pattern & & & Longitudinal and parallel grooves & Longitudinal and parallel grooves \\
\hline & Secondary colour pattern & Green & Green & Dark green & Dark green \\
\hline & Thickness (mm) & $12.3 \pm 1.2$ & $12.3 \pm 2.2$ & $10.7 \pm 1.6$ & $10.1 \pm 1.4$ \\
\hline & Pubescence & Pilose & Pilose & Scabrous & Scabrous \\
\hline & Tendrils & Simple, one each node & Simple, one each node & Simple, one each node & Simple, one each node \\
\hline \multirow{16}{*}{ LEAF } & Shape & Entire & Entire & Entire & Entire \\
\hline & Lobes & Shallow & Very shallow & Shallow & Shallow \\
\hline & Length of terminal lobe & Medium & Short & Short & Short \\
\hline & Secondary lobation & Absent & Absent & Absent & Absent \\
\hline & Margin dentation & Weak & Weak & Intermediate & Intermediate \\
\hline & Blade blistering & Very weak & Weak & Weak & Weak \\
\hline & Leaf colour & Green & Green & Green & Green \\
\hline & Prominence of leaf vein & Present & Present & Present & Present \\
\hline & $\begin{array}{l}\text { Pigmentation of leaf vain } \\
\text { (colour) }\end{array}$ & $\begin{array}{l}\text { Absent } \\
\text { (lioghtoreen }\end{array}$ & $\begin{array}{l}\text { Absent } \\
\text { (liabtorreen) }\end{array}$ & $\begin{array}{l}\text { Absent } \\
\text { (liaghtoen }\end{array}$ & $\begin{array}{l}\text { Absent } \\
\text { (liaghtoreen }\end{array}$ \\
\hline & $\begin{array}{l}\text { (colour) } \\
\text { Leaf size }\end{array}$ & (light green) & (light green) & (light green) & (light green) \\
\hline & & $18.7 / 24.0$ & $19.4 / 21.7$ & $10.8 / 15.0$ & $13.7 / 17.8$ \\
\hline & Length/width ratio ${ }^{4}$ & 0.78 & 0.88 & 0.72 & 0.77 \\
\hline & Petiole length $(\mathrm{cm})^{4}$ & 20 & 15 & 13 & 13 \\
\hline & Petiole colour & Green & Green & Green & Green \\
\hline & $\begin{array}{l}\text { Petiole attitude: } \\
\text { principal stem }{ }^{4}\end{array}$ & Erect & Erect & - & - \\
\hline & $\begin{array}{l}\text { Petiole attitude: } \\
\text { primary stem }\end{array}$ & Erect & Horizontal & Semi-erect & Semi-erect \\
\hline
\end{tabular}


Table 1. Cont.

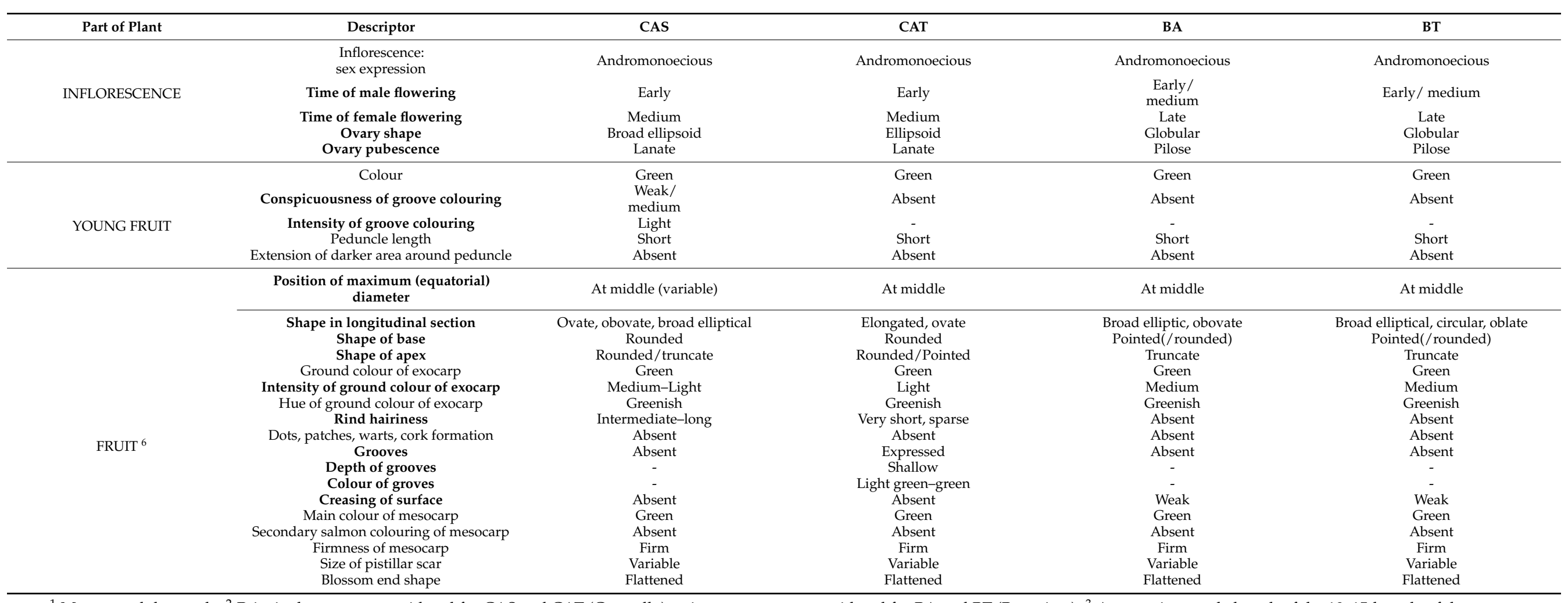

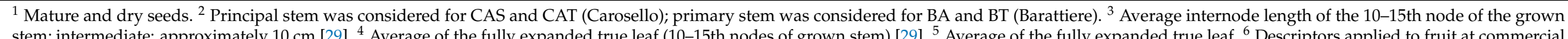
maturity stage. Numerical values of fruit biometrical traits are reported in Table 2. 
Table 2. Biometric traits of commercially mature fruits of two commercial cucumbers, 'Baby Star' and 'Modan', and four local genotypes, Carosello 'Scopatizzo', Carosello 'Tomentoso', Barattiere 'Allungato' and Barattiere 'Tondo'. Values are average \pm standard deviation of fruits harvested during the entire growing cycle from three replicates.

\begin{tabular}{|c|c|c|c|c|c|c|c|}
\hline Genotype & $\begin{array}{c}\text { Fruit } \\
\text { Length }\end{array}$ & $\begin{array}{c}\text { Equatorial } \\
\text { Diameter }\end{array}$ & $\begin{array}{c}\text { Polar } \\
\text { Diameter }\end{array}$ & $\begin{array}{l}\text { Mesocarp } \\
\text { Thickness }\end{array}$ & $\begin{array}{l}\text { Endosperm } \\
\text { Width }\end{array}$ & $\begin{array}{l}\text { Endosperm } \\
\text { Length }\end{array}$ & $\begin{array}{l}\text { Fruit Length/ } \\
\text { Width Ratio }\end{array}$ \\
\hline & \multicolumn{7}{|c|}{$\mathrm{mm}$} \\
\hline Cucumber 'Baby Star' & $119.6 \pm 3.8$ & $42.1 \pm 0.3$ & $32.3 \pm 1.1$ & $9.17 \pm 0.1$ & $26.31 \pm 0.5$ & $100.1 \pm 3.5$ & $2.84 \pm 0.1$ \\
\hline Cucumber 'Modan' & $188.3 \pm 3.0$ & $39.8 \pm 0.2$ & $29.8 \pm 1.2$ & $10.58 \pm 0.3$ & $23.72 \pm 0.8$ & $163.2 \pm 4.7$ & $4.73 \pm 0.06$ \\
\hline Carosello 'Scopatizzo' & $94.8 \pm 3.8$ & $70.6 \pm 2.1$ & $45.9 \pm 2.0$ & $17.33 \pm 0.7$ & $38.58 \pm 1.6$ & $61.7 \pm 2.2$ & $1.34 \pm 0.06$ \\
\hline Carosello 'Tomentoso' & $110.6 \pm 4.0$ & $49.9 \pm 1.1$ & $38.3 \pm 2.1$ & $10.88 \pm 0.8$ & $29.33 \pm 0.1$ & $87.1 \pm 3.5$ & $2.22 \pm 0.09$ \\
\hline Barattiere 'Allungato' & $90.9 \pm 0.3$ & $85.0 \pm 2.4$ & $58.0 \pm 0.8$ & $18.72 \pm 0.2$ & $49.64 \pm 2.1$ & $54.6 \pm 0.9$ & $1.07 \pm 0.04$ \\
\hline Barattiere 'Tondo' & $88.4 \pm 3.0$ & $83.8 \pm 1.6$ & $57.7 \pm 1.9$ & $19.74 \pm 1.2$ & $46.52 \pm 1.3$ & $53.7 \pm 1.4$ & $1.05 \pm 0.04$ \\
\hline \multicolumn{8}{|l|}{ Significance $^{1}$} \\
\hline Cucumbers vs. Others & * & * & * & * & * & * & * \\
\hline Barattiere vs. Carosello & * & * & * & * & * & * & * \\
\hline Cucumbers & * & ns & ns & ns & ns & * & * \\
\hline Carosello & $*$ & $*$ & $*$ & * & $*$ & $*$ & * \\
\hline Barattiere & ns & ns & ns & ns & * & ns & Ns \\
\hline
\end{tabular}

${ }^{1}$ Significance of contrasts: ${ }^{*}=p \leq 0.05 ; \mathrm{ns}=$ not significant.

Full-grown stems and leaf petiole displayed longitudinal parallel glabrous grooves, which were deeper and dark green in Barattiere, shallow and light green in Carosello; outside the grooves, the vestiture of epidermis was pilose (quite soft straight orthogonal trichomes) in Carosello and scabrous (stiff orthogonal trichomes) in Barattiere (Table 1). On average, the principal stem of Carosello plants grew thicker (approximately 17\%) than the grown primary stem of Barattiere.

Leaves showed some differences (Figure 4); however, variability was observed in the same plants, and leaf shape and margins varied during the leaf expansion.
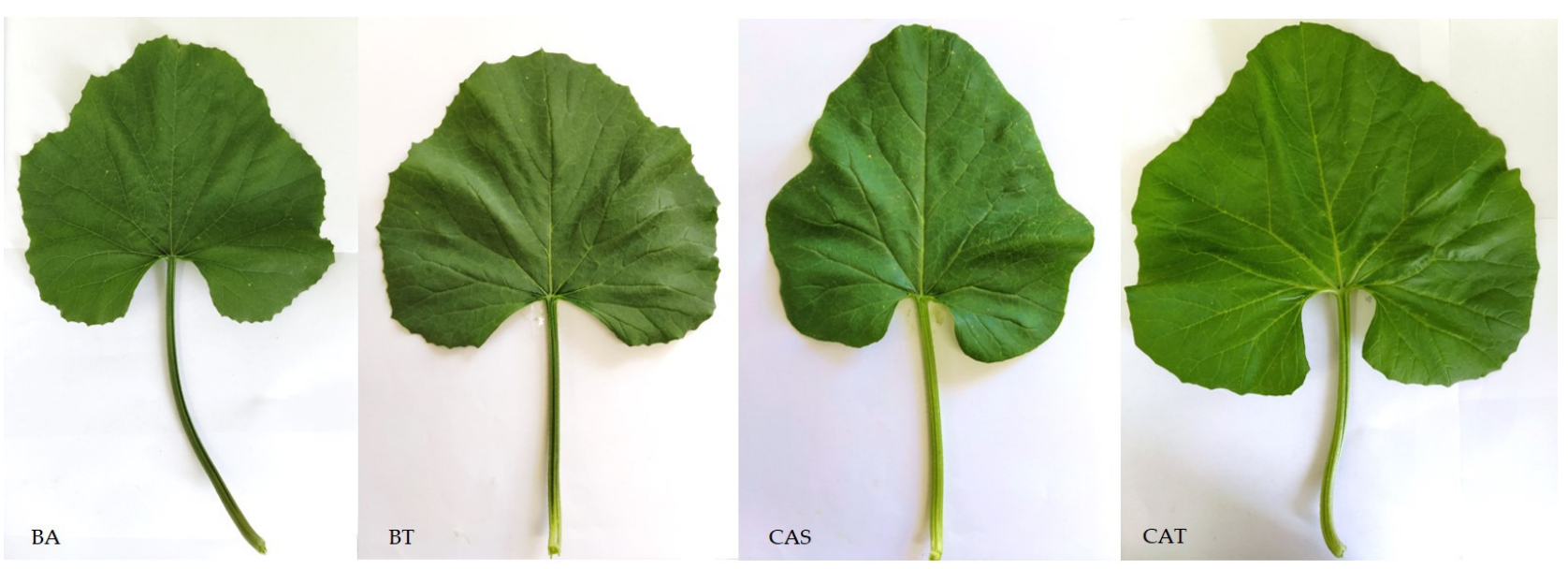

Figure 4. Fully expanded leaves of unripe melon genotypes (from left to right: Barattiere 'Allungato' (BA), Barattiere 'Tondo' (BT), Carosello 'Scopatizzo' (CAS), Carosello 'Tomentoso' (CAT) collected at 50\% flowering. BA and BT: leaf from vertically trained primary stem; CAS and CAT; leaf from the vertically trained principal stem. Leaves in different scales).

Prominent discriminating leaf features were: accentuated dentation and cordate shape in Barattiere rather than Carosello; fully expanded leaves of Barattiere were darker compared to Carosello ones; leaf size (length, width; stem of belonging) was generally higher for CAT (19.4, $21.7 \mathrm{~cm}$; principal stem leaf) followed by CAS (18.7, $24.0 \mathrm{~cm}$; principal stem leaf) compared to Barattiere genotypes (12.3, $16.4 \mathrm{~cm}$; primary stem leaf). Although 
further different features were identified, they were highly variable, e.g., petiole attitude (Table 1). The petiole was deeper caniculate in Barattiere rather than Carosello; however, all landraces had a main longitudinal channel on the adaxial surface, and it was more evident in fully grown leaves.

The sex expression was andromonoecious in accordance with the previous observation on Carosello, Barattiere [35], and wild melons [32]. The principal stem of CAS and CAT provided only staminate flowers, except for the fruit-bearing basal rosette of CAT, whereas the primary stem of all genotypes exhibited both staminate and perfect flowers (bisexual flowers), and the former flowered earlier than the latter. Barattiere started to flower later than Carosello. The botanical floral characters were shared between local genotypes. The flowers were pedicellate and the pedicel was glabrous and commonly thinner and longer in staminate flowers than in perfect flowers; the calix was composed by five small green sepals and five yellow petals, which were partially fused at the base to form a short corolla tube on the top of the inferior ovary. Ovary shape and pubescence differed between genotypes: the Carosello ovary was lanate, ellipsoid in CAT and broad ellipsoid in CAS; the Barattiere ovary was pilose and tendent to a globular shape (Figure 5). The size of the pedicel, corolla and ovary were variable in the same plant.
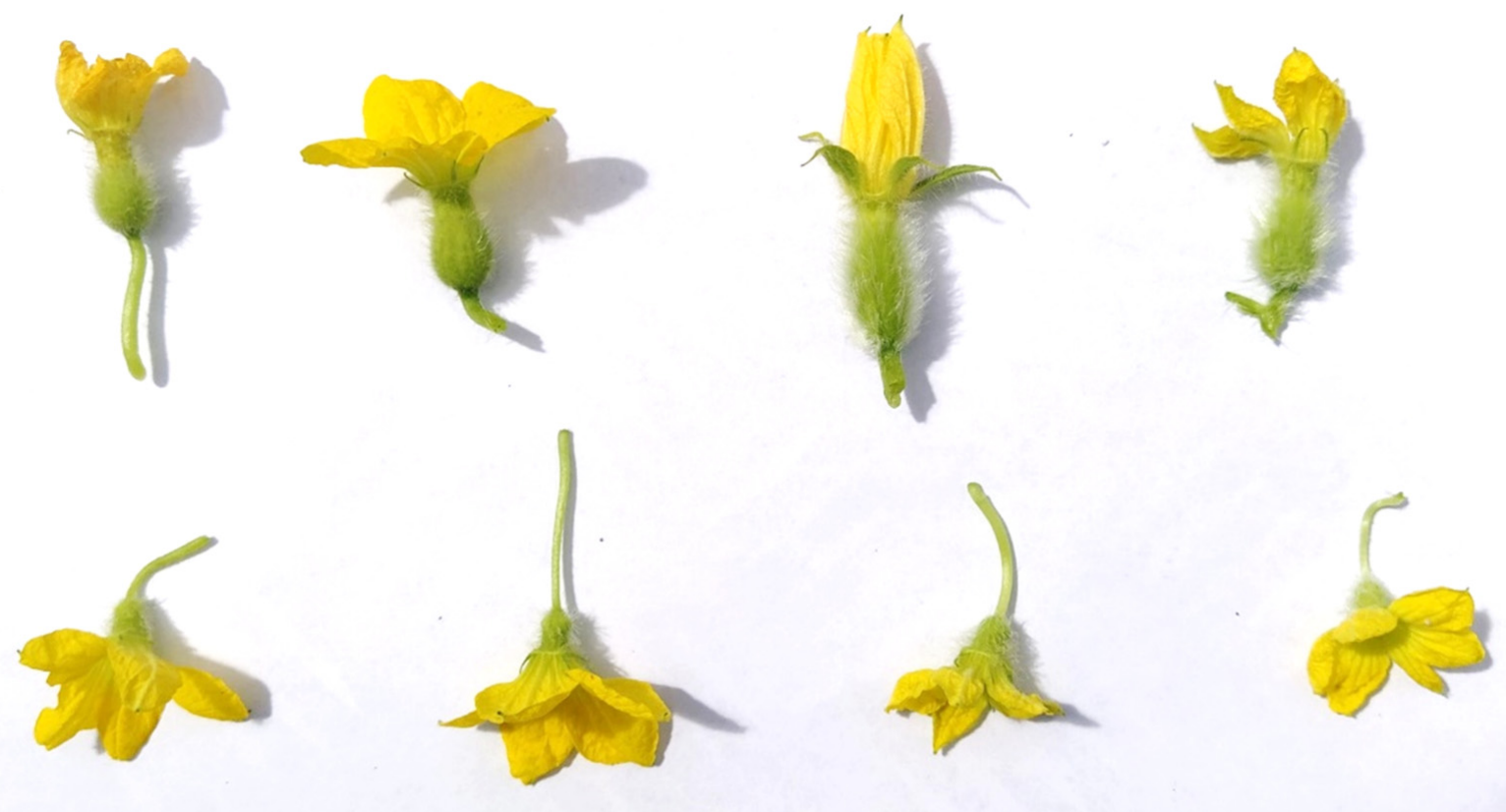

Figure 5. Perfect flower (top row) and male flowers (bottom row) of local melon genotypes (from left to right: Barattiere 'Allungato' (BA), Barattiere 'Tondo' (BT), Carosello 'Tomentoso' (CAT), Carosello 'Scopatizzo' (CAS)).

Both types of flowers had a floral nectary, and the androecium consisted of five connate stamens producing viable pollen (Figure $6 \mathrm{a}-\mathrm{d}$ ). The style and stigma of the landraces had similar characteristics. Compared to the cucumber female flower, the style of local melons was shorter and the stigma was usually smaller; both were greenish and the nectary was yellowish instead of white to pale yellow (Figure 6e). The full pistil and the abovementioned related features are represented in Figure 6f. 


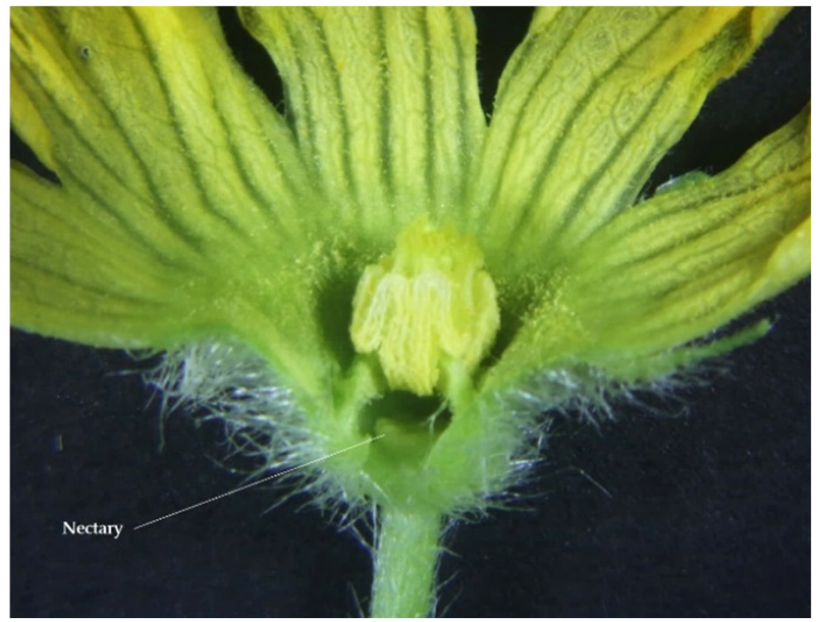

(a)

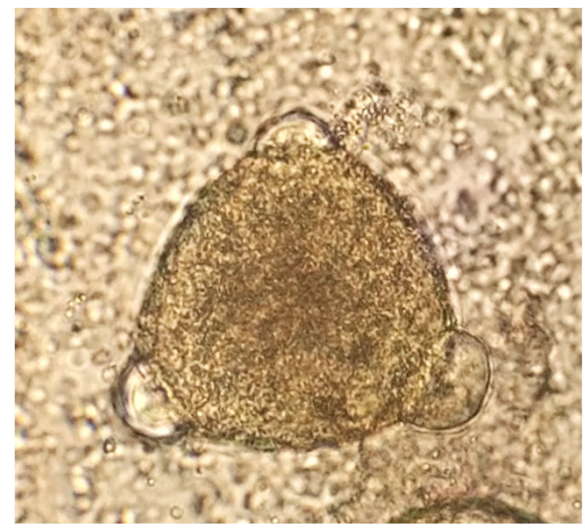

(c)

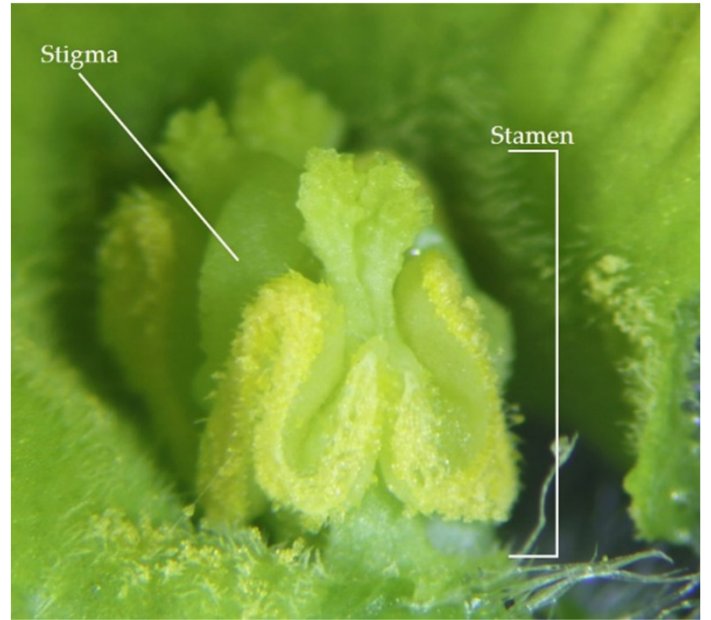

(b)

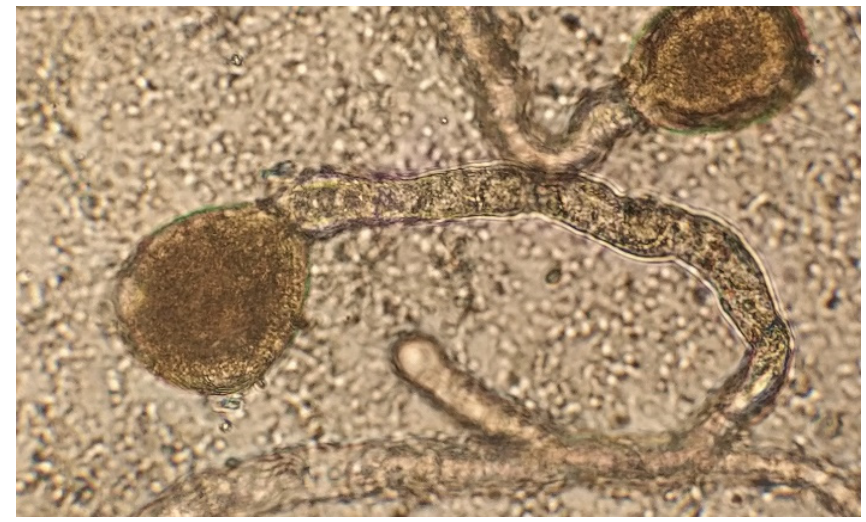

(d)

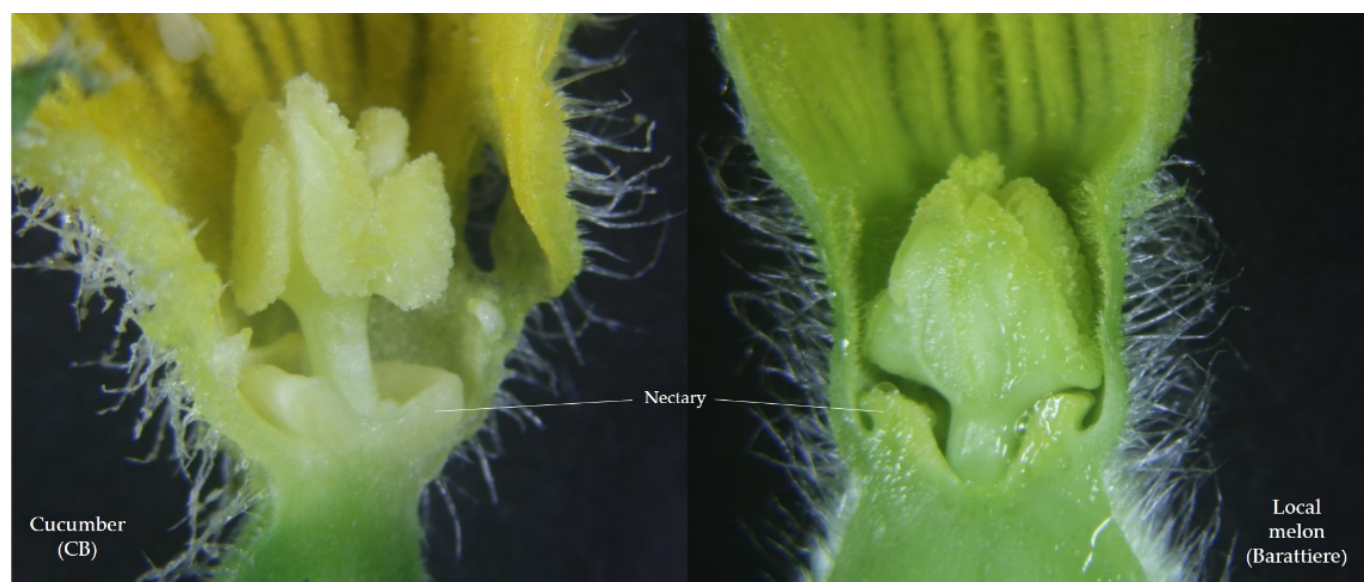

(e)

Figure 6. Cont. 


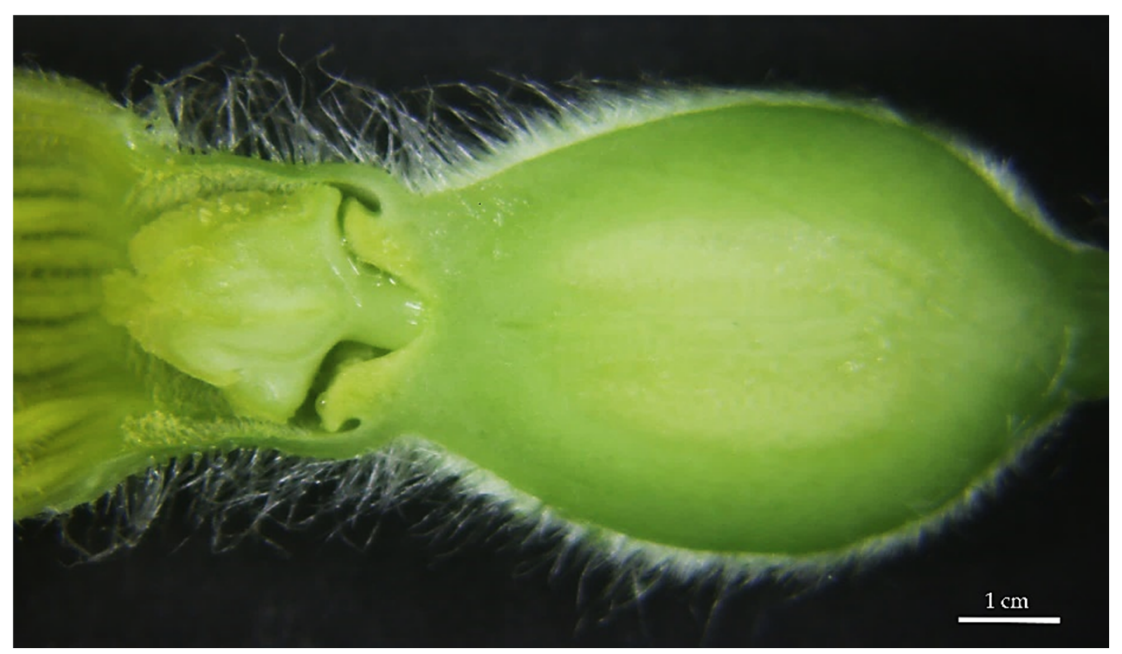

(f)

Figure 6. Details of flowers. (a) Pistillate flower of Barattiere 'Allungato' (BA): androecium and nectary; (b) detail of perfect flower of Carosello 'Scopatizzo', stamen and stigma; (c) viable pollen grain of Carosello 'Tomentoso' (CAT) starting to germinate; (d) germinated pollen grain and pollen tube of CAT; (e) comparison between style and stigma of pistillate flower of cucumber (left) and perfect flower of Barattiere 'Allungato' (right) in longitudinal section, stamens manually removed; (f) longitudinal section of pistil of BA.

Pubescence was spread on the plant of all genotypes and consisted of multicellular, unbranched, uniseriate tapering trichomes (Figure 7).

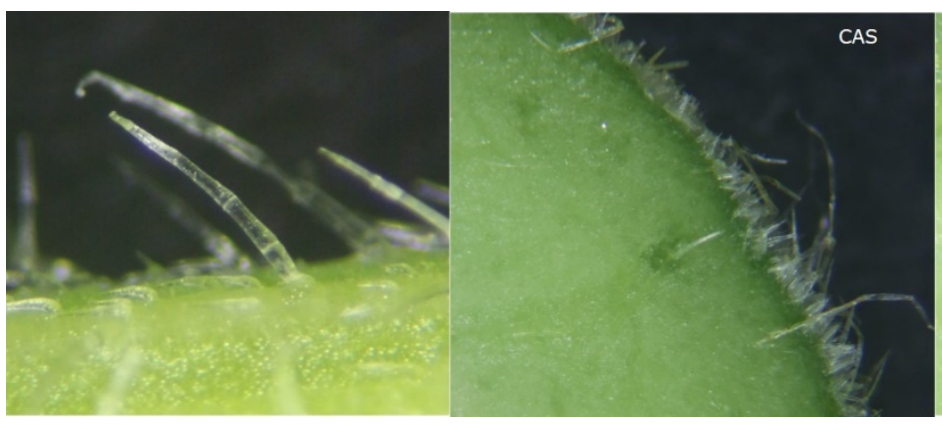

(a)

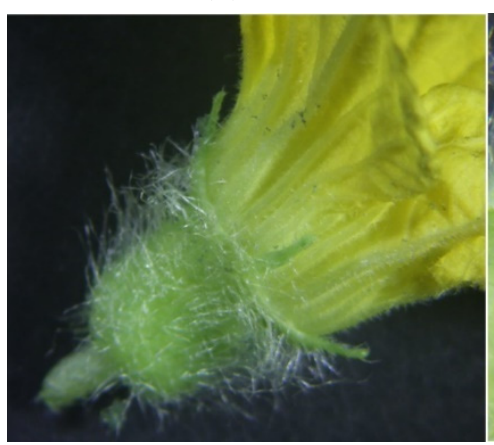

(d) (b)

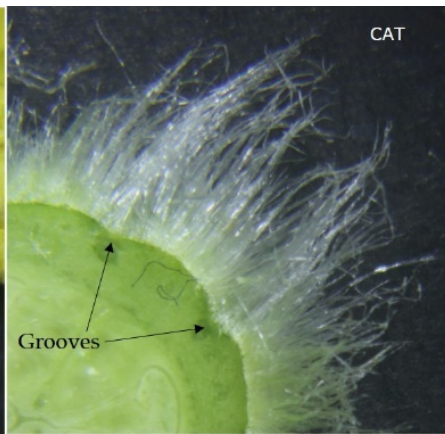

(e)

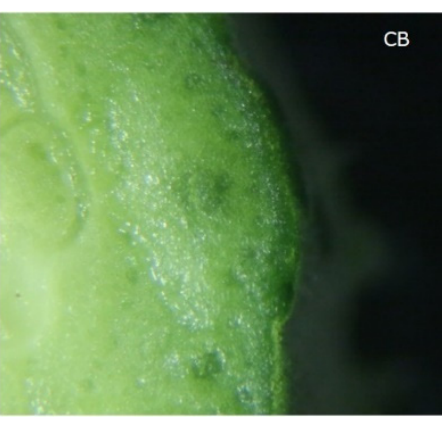

(c)

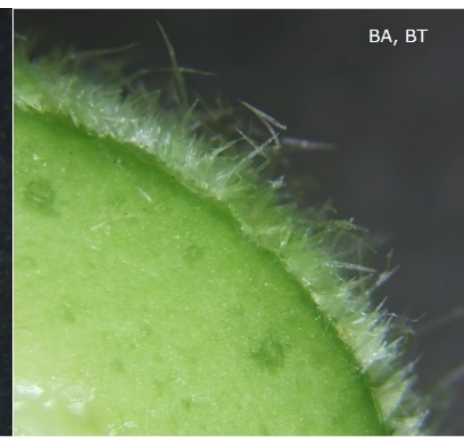

(f)

Figure 7. Details of pubescence: (a) Trichomes of leaf vein of Carosello 'Scopatizzo' (CAS); (b) cross-section of young fruit of CAS; (c) cross-section of young fruit of cucumber 'Baby star' (CB); (d) Pubescence of floral parts of staminate flower of CAS; (e) cross-section of young fruit of Carosello 'Tomentoso' (CAT), arrows point grooves; (f) cross-section of young fruit of Barattiere 'Allungato' and 'Tondo' (BA and BT). 
The young fruits were all green, with a short peduncle not surrounded by a darker area. CAT had shallow grooves compared to the smooth surface of other young fruits (Figure $7 b, c, e, f)$. Pubescence of young fruits decreased from fruit set to the following growth stages; only CAT fruits preserved a lanate pubescence until harvest.

The size, shape, and colour of commercially mature fruits and productive parameters are described and discussed in Sections 3.2 and 3.3. Remarkable differences were found between abundant intermediate $(<1 \mathrm{~cm})$ to long $(>1 \mathrm{~cm})$ rind hairiness of CAT fruit and the minimal hairiness of CAS and the glabrous rid of Barattiere. Furthermore, they also differed in the surface type: CAT showed longitudinal shallow grooves of variable depth depending on the fruit growth stage and the natural variability; the CAS skin was smooth; the Barattiere skin was characterized by weak creases, deeper in the peduncular zone and in the harvested fruits besides older and more expanded ones. Surface differences were attenuated during fruit maturation.

The morphological plant description is in accordance with previous descriptions for these landraces and partially with wild melon features described by Pitrat [32], for example, sex expression, fruit morphology, and colour of flesh.

In the view of agrobiodiversity preservation, these results based on official descriptors $[28,29]$ can be useful in support of the recognition of "conservation variety" status for the tested melon landraces in the register of varieties of the European Union. The inclusion in this register is an important step for landraces towards farmer attention and consequent valorisation. Furthermore, agricultural and commercial interests play a decisive role in the improvement of genotypes and in their diffusion [5].

\subsection{Fruit Yield and Biometrics}

Harvest started on different days depending on the genotypes: cucumbers 23 days after transplanting (DAT); CAT 45 DAT; CAS 49 DAT; BA and BT 68 DAT.

The biometrics reported in Table 2 confirmed the fruit shapes described in Table 1 and displayed in Figure 8. The cucumbers produced the longest and narrowest fruits corresponding to a length/width ratio $>1$ or elongate shape, particularly for CS. Barattiere produced the shortest and widest fruits and a consequent length/width ratio close to 1, representing a circular shape; Carosello fruits had intermediate dimensions, namely CAS tending to circular and CAT to elongate. Similar relations were measured for the endosperm dimensions, with the exception of endosperm width in Barattiere. Concerning the polar diameter at the fruit apex, the cucumbers produced fruits with the most rounded apex; Barattiere had a significantly narrower shape compared to Carosello, namely a more pointed and rounded fruit apex, respectively. The mesocarp thickness was significantly different between genotypes groups: the cucumbers had the thinnest mesocarp, followed by CAT; Barattiere had the thickest mesocarp $(76.9 \%$ and $94.7 \%$ thicker than CAT and cucumbers, respectively); the mesocarp of CAS was significantly thicker than CAT by $59.3 \%$ and thinner than Barattiere by $9.9 \%$.

Overall, the cucumbers' fruit differs significantly in all parameters compared to the landraces; the Barattiere and Carosello groups differ in all parameters as well. Comparing two Barattiere genotypes, their fruits are very similar; the cucumbers also showed similar fruit traits with the exception of length. On the contrary, the fruits of the Carosello genotypes are clearly dissimilar: the CAT fruit is closer to cucumbers, the CAS fruit to Barattiere.

Descriptive and biometric analyses indicate that the CAS fruit is morphologically closer to Barattiere rather than the other Carosello (CAT) (Figure 8a-d). Moreover, a different level of variability was observed in fruit shape (Table 1): absent for cucumbers; very low for CAT; quite moderate for Barattiere and limited to peduncular zone and fruit elongation; more evident in CAS fruits in terms of the position of the equatorial diameter along the longitudinal axis and apex and base roundness, which contributed to higher variability in the fruit shape. Additionally, the external appearance of the CAS fruit is also decisively different from CAT in terms of pubescence (Table 1; Figure 8), which characterises only CAT, and to a smaller extent in exocarp colour (Figure 9). The same differences were 
observed by Conversa et al. [8]. Despite the folk name 'Scopatizzo' being traditionally attributed to a type of Carosello [8,13], mistakes are common in the attribution of these groups $[1,6]$. Furthermore, molecular approaches found that some ecotypes with the folk name including 'Scopatizzo' are genetically differentiated and they are not decisively attributable to the Carosello group [36]. On the other hand, plant descriptions did not suggest substantial differences [8], with the exception of the basal rosette of CAT.

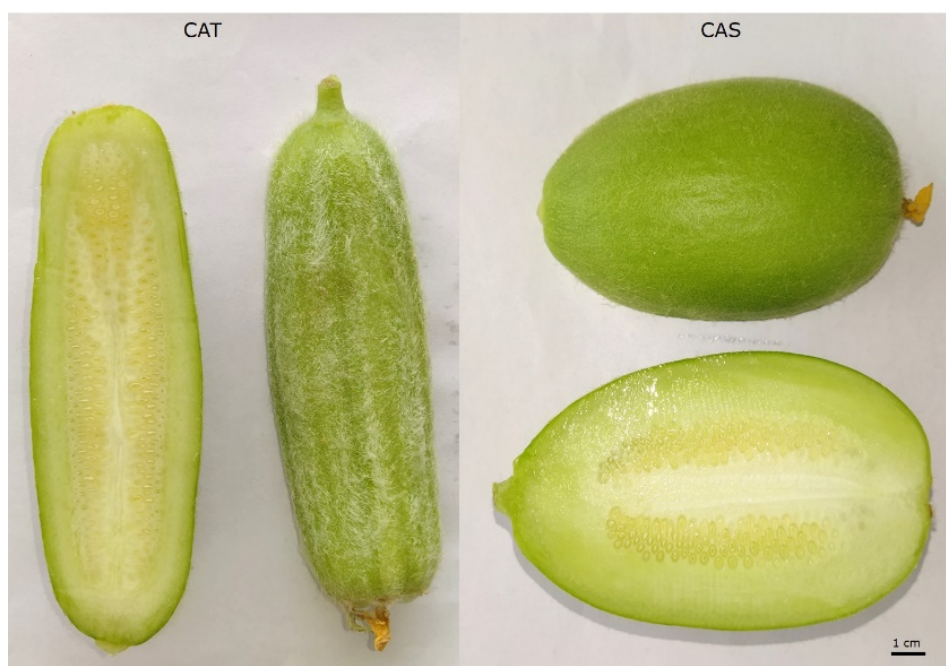

(a)

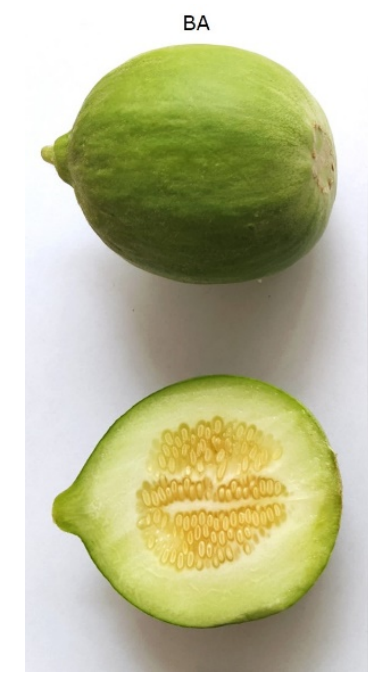

(c)

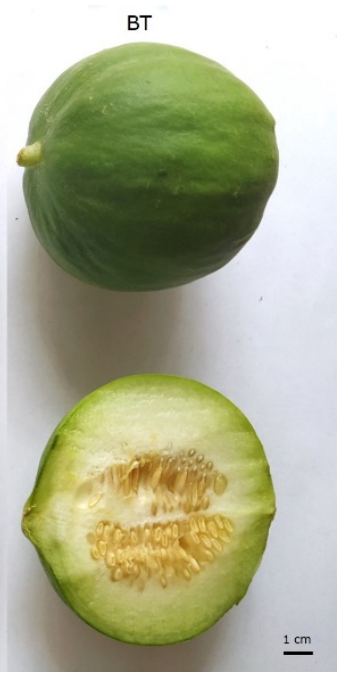

(d)

Figure 8. External view and longitudinal section of harvested fruits of unripe melon landraces: (a) Carosello 'Tomentoso' (CAT); (b) Carosello 'Scopatizzo' (CAS); (c) Barattiere 'Allungato' (BA); (d) Barattiere 'Tondo' (BT).

BA and BT showed low significant dissimilarity in the analysis and the main morphological descriptors were identical (Tables 1-3). Considering the ambiguity of these genotypes and the confusion in name attribution by seed sellers, we tend to believe that BA and BT seeds belonged to Barattiere 'Tondo', thus the differences observed were caused by environmental influence and well-known variability of the landrace $[1,8]$.

Table 3. Productive parameters of cucumber (C. sativus 'Baby Star' and 'Modan') and four landraces (Carosello 'Scopatizzo', Carosello 'Tomentoso', Barattiere 'Allungato', Barattiere 'Tondo') of C. melo. Harvest referred to the duration of the experiment and three replicates. Fruits appropriate for the market were considered.

\begin{tabular}{|c|c|c|c|}
\hline \multirow{2}{*}{ Genotype } & Number of Fruits & Yield & Fruit Dry Matter \\
\hline & $n \cdot$ Plant $^{-1}$ & g.Plant ${ }^{-1}$ & $\mathrm{~g} \cdot 100 \mathrm{~g}^{-1} \mathrm{FW}$ \\
\hline Cucumber 'Baby Star' & $14.5 \pm 1.4$ & $1620 \pm 117.6$ & $3.40 \pm 1.2$ \\
\hline Cucumber 'Modan' & $16.9 \pm 0.7$ & $2877 \pm 66.0$ & $4.04 \pm 0.9$ \\
\hline Carosello 'Scopatizzo' & $10.5 \pm 3.4$ & $2618 \pm 922.0$ & $4.53 \pm 0.8$ \\
\hline Carosello 'Tomentoso' & $17.0 \pm 5.5$ & $2520 \pm 749.3$ & $3.69 \pm 1.0$ \\
\hline Barattiere 'Allungato' & $3.2 \pm 0.4$ & $1031 \pm 169.8$ & $4.32 \pm 0.8$ \\
\hline Barattiere 'Tondo' & $4.1 \pm 0.6$ & $1228 \pm 214.0$ & $3.97 \pm 0.6$ \\
\hline \multicolumn{4}{|l|}{ Significance $^{1}$} \\
\hline Cucumbers vs. Others & * & ns & ns \\
\hline Barattiere vs. Carosello & * & $*$ & ns \\
\hline Cucumbers & ns & * & ns \\
\hline Carosello & * & ns & $*$ \\
\hline Barattiere & $\mathrm{ns}$ & ns & ns \\
\hline
\end{tabular}

\footnotetext{
${ }^{1}$ Significance of contrasts: ${ }^{*}=p \leq 0.05 ; \mathrm{ns}=$ not significant.
} 

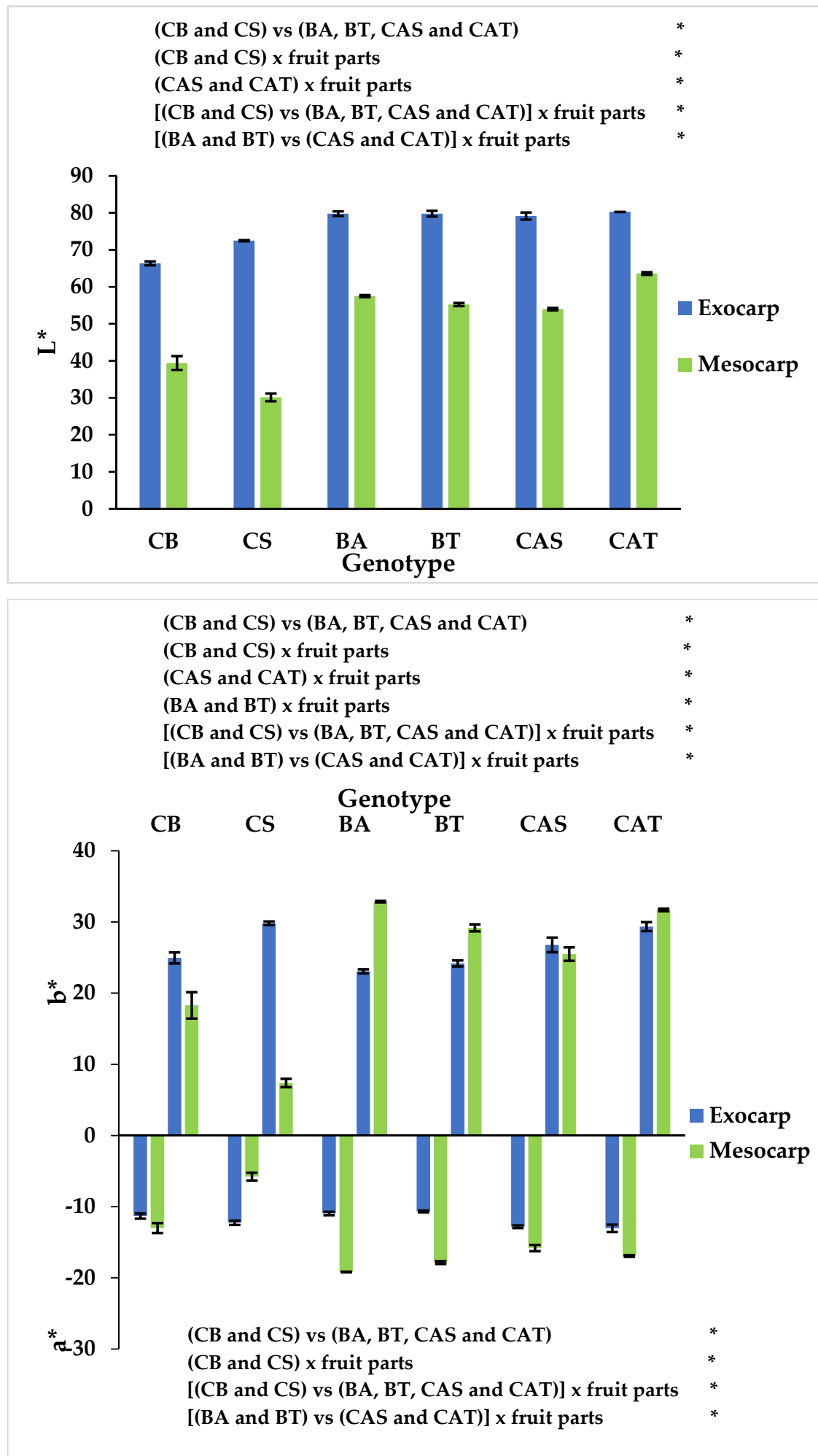

Figure 9. Cont. 

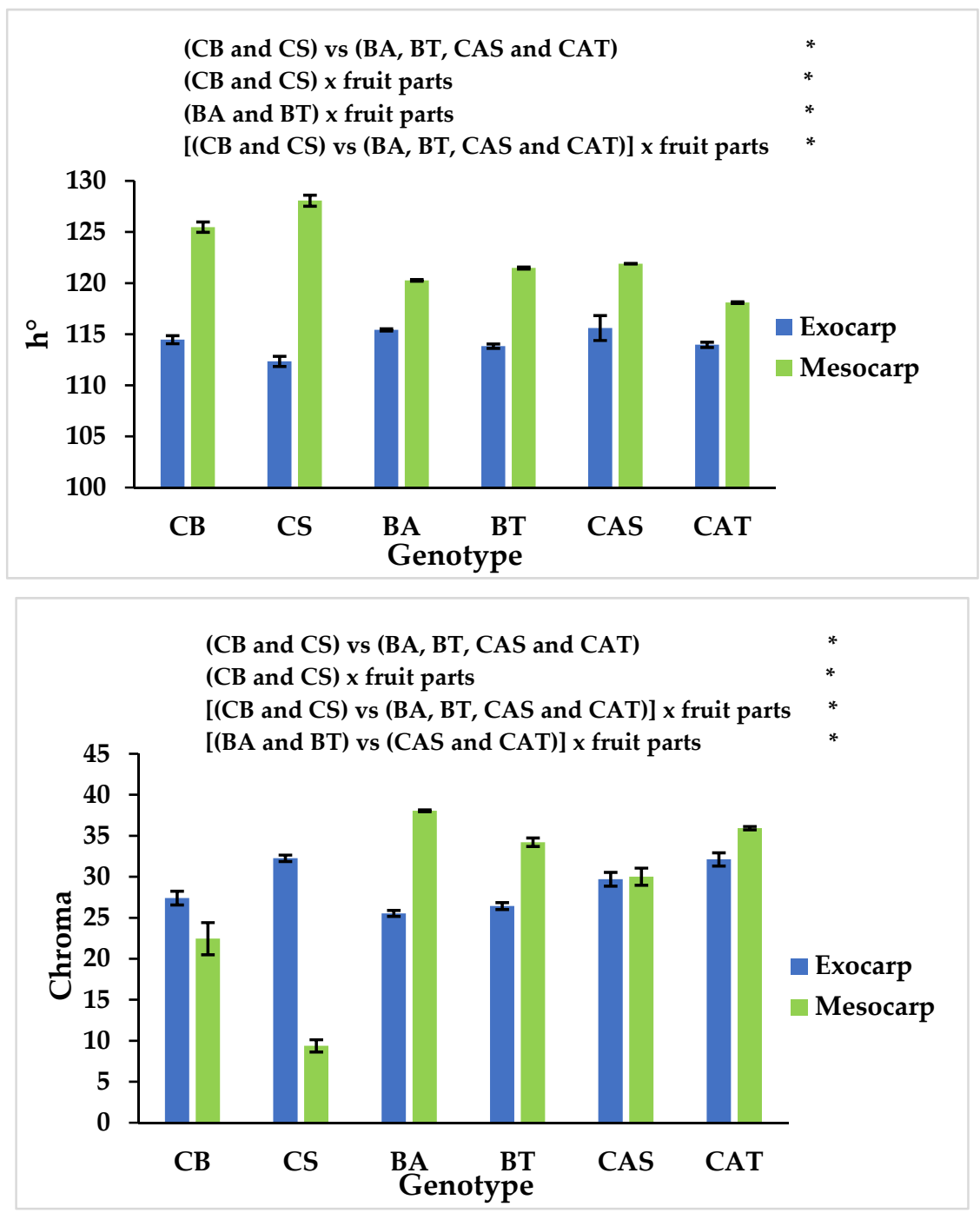

Figure 9. Colour parameters of fruit harvested at commercial maturity referring to cucumber 'Baby Star' (CB), cucumber 'Modan' (CS), Carosello 'Scopatizzo' (CAS), Carosello 'Tomentoso' (CAT), Barattiere 'Allungato'(BA), Barattiere 'Tondo'(BT) and fruit parts (exocarp and mesocarp). Values are the average of three replicates. Parameters refer to CIELAB colour system: L*, lightness; $\mathrm{a}^{*}$, $\mathrm{red}(+)$ /green(-) chromaticity, and $\mathrm{b}^{*}$, yellow $(+) /$ blue $(-)$ chromaticity; $\mathrm{h}^{\circ}$, hue angle; $\mathrm{C}$, chroma. Text in the chart refers to significant contrasts between genotype groups and interaction between genotype groups and fruit parts; significance of contrasts: ${ }^{*}=p \leq 0.05$.

The productive parameters contrasted between genotype groups; fruit dry matter was significantly different only within the Carosello group (Table 3). The cucumbers produced more fruits (average of 15.7 per plant) than the landraces (average of 8.7); however, Carosello produced $277 \%$ more fruit by plants than Barattiere. Furthermore, a significant divergence was observed within the Carosello group: CAT produced more than twice (61.9\%) the number of fruits of the CAS plants and was closer to the cucumbers. The yield data also highlighted a contrasting production between Carosello and Barattiere; however, the landraces reached a yield comparable to that of cucumbers.

Productive parameters suggest that landraces can be an alternative to commercial cucumbers in terms of productivity in a rockwool soilless system in a glasshouse outside the natural crop season. Carosello, particularly for CAT, achieved this result for the considerable number of fruits produced by plant, which was comparable to cucumber hybrids. Barattiere also accomplished an interesting yield. Nevertheless, the Barattiere fruits and CAS fruits are appropriate to market with a wide range of weights, different 
from CAT [8]. The low number of fruits produced by plants can be compensated by their bigger size. Similar conclusions were reported by Bonasia et al. [35].

Higher productions (number of fruits per plant and yield) and dry matter were measured in an open field and soilless systems within the spring season, particularly for Barattiere [9,35]. Different productions are compatible with the different growing season, which was unfavourable for melon landraces in our experiment. The above reported low production of Barattiere is attributable to the delay in germination and consequently in growth compared to other genotypes. Parente et al. [9] reported that Carosello could be more able to counteract thermal stresses compared to Barattiere, especially in soilless systems. Moreover, Barattiere produces fruits later than Carosello due to the reproductive habitus [8,9]. In addition to tardive entry into production (approximately three weeks later in this experiment) and the consequent short productive period available up to the closure of the experiment, literature reports a slower productivity (lower number of fruits produced) of Barattiere at the beginning of the productive period compared to other local genotypes [35].

\subsection{Colour Analysis}

Colour parameters varied among groups (Figure 9). Cucumber fruit colour was significantly darker $\left(24.1 \% \mathrm{~L}^{*}\right)$ than landraces; CAT fruits were the lightest $(27.8 \%$ more than cucumbers); other genotypes displayed intermediated lightness. Compared to local melons, cucumbers were greener $\left(27.9 \% \mathrm{a}^{*}\right)$ and less yellow $\left(27.7 \% \mathrm{~b}^{*}\right)$. Hue was higher for cucumbers (2.2\%) than landraces; within Carosello, CAS hue was 2.3\% higher than CAT. Chroma differs between all genotypes except for the contrast between Carosello and Barattiere.

Overall, the fruit parts' mesocarp (inner layer) and exocarp (external layer) differed in colour parameters, except $C$ (Figures 8 and 9). Some interactions between genotype groups and fruit parts gave significantly different results (Figure 9). Significative contrasts for all parameters were measured for the interaction between two cucumbers in relation to their parts and for the interaction between cucumbers and local genotypes in relation to their parts: the cucumbers' exocarp showed higher values of $a^{*}$ and $b^{*}$ and lower $C$ compared to the mesocarp; an opposite characterization was described in local genotypes fruits, with the exception of $b^{*}$ in CAS. Barattiere and Carosello contrast varied for all parameters except $h^{\circ}$. Referring to the interaction within the parts and the genotype, CAS and CAT differed in lightness and $\mathrm{b}^{*}$; BA and BT in $\mathrm{h}^{\circ}$.

The colour analysis results were in accordance with the literature: for all tested genotypes, the main colour is green for the exocarp and light green for the mesocarp at harvest (Figure 8) [1,37]. The chromaticity indicators suggest that the Carosello skin is light green and slightly yellow, especially for CAT. The Barattiere skin can be described as greenish and slightly yellow [7]. Both landraces are lighter than cucumbers. The colour appearance of vegetables is an important qualitative parameter and contributes to the aesthetics and the appeal to the consumers. The skin colour of the tested landraces can be considered a first discriminating element against cucumbers to help the consumer to accept Carosello, 'Scopatizzo' and Barattiere as a separate vegetable, instead of a local cucumber. The mesocarp is lighter and generally more yellow than the exocarp, thus it can be identified as light green-yellow [7] at harvest.

\subsection{Chlorophyll and Fluorescence Parameters}

Leaf chlorophyll content was higher (81.5\%) in cucumbers than in local melons (data not shown). Although the same amount of pigment was measured in CAT, BA, and BT (approximately $145 \mu \mathrm{mol} \cdot \mathrm{m}^{-2}$ ), a significant contrast was found between Carosello and Barattiere. Within the Carosello group, the chlorophyll content in CAT was $24.5 \%$ higher than in CAS, which reached the lowest content $\left(111 \mu \mathrm{mol} \cdot \mathrm{m}^{-2}\right)$.

Overall, the fluorescence parameters scarcely varied between groups (data not shown). Although the cucumbers differed from the landraces in terms of maximal $\left(\mathrm{F}_{\mathrm{m}}{ }^{\prime}\right)$ and ground 
fluorescence $\left(\mathrm{F}_{0}{ }^{\prime}\right)$ after the light pulse, the $\mathrm{F}_{\mathrm{V}} / \mathrm{F}_{\mathrm{m}}$ ratio is similar between groups. This implies that the maximum quantum yield of PSII is not significantly different in tested genotypes in the relative environmental contest. BA reached the same $\mathrm{F}_{\mathrm{m}}$ ' starting from a lower $\mathrm{F}_{0^{\prime}}$; this can lead to the speculation that the PSII functionality can be better for BA than BT.

\section{Conclusions}

The characterisation of the landraces Barattiere and Carosello (Cucumis melo L.) was successfully obtained by the application of morpho-physiologic descriptors of melons. As confirmation of the recurring problem of synonymy and homonymy due to the high variability of these landraces, unexpected similarities emerged within the Barattiere group. This suggested that two different names, Barattiere 'Allungato' and Barattiere 'Tondo', were erroneously attributed to the same landrace (Barattiere 'Tondo') from the local nursery. In accordance with the well-known wide and various range of traits of local melons, significant differences were found between the Carosello genotypes. On the basis of the lack of basal rosette, fruit shape, and pubescence, Carosello 'Scopatizzo' may resemble Barattiere; nevertheless, leaf traits, productive parameters, stem patterns, flowering timing, fruitful flower distribution, and general hairiness are shared with Carosello 'Tomentoso'. Genetic and molecular insights are certainly required to clarify the classification and denominations of Barattiere and Carosello.

In conclusion, the detailed knowledge of plant habitus and sex expression allowed the implementation of appropriate agronomical practices and a competitive production with commercial cucumbers. The cultivation of these landraces in rockwool soilless systems under a supplemental LED light with a vertical training of one stem and tipping of lateral stems at the second node were effective to grow the plants outside the natural growing season. Both Carosello and Barattiere reached the expected production levels. Moreover, the Carosello production was comparable to that of commercial hybrids of cucumbers grown in the same conditions.

In accordance with these remarks, we suggest extending the morphological and molecular characterization to other landraces and further implementing appropriate agronomic techniques, with the final aim of preserving and promoting the local biodiversity.

Author Contributions: Conceptualization, A.S. (Annalisa Somma), O.D.P., M.R. and P.S.; methodology, A.S. (Annalisa Somma), O.D.P., M.R. and P.S.; validation, P.S.; formal analysis, P.S.; investigation, A.S. (Annalisa Somma), O.D.P., B.L. and A.S. (Angelo Signore); resources, P.S.; data curation, P.S.; writing—original draft preparation, A.S. (Annalisa Somma); writing—review and editing, P.S.; visualization, A.S. (Annalisa Somma), O.D.P.; supervision, P.S.; project administration, P.S.; funding acquisition, P.S. All authors have read and agreed to the published version of the manuscript.

Funding: This research was funded by the Rural Development Programme of the Apulia Region (Italy) 2014-2020, Submeasure 16.2 (Support for pilot projects and development of new products, practices, processes and technologies, and transfer and dissemination of results obtained by Operational Groups), in the framework of the SOILLESS GO project, project code (CUP) B97H20000990009, paper n. 11.

Institutional Review Board Statement: Not applicable.

Informed Consent Statement: Not applicable.

Data Availability Statement: The raw data supporting the conclusions of this article will be made available by the authors, without undue reservation.

Acknowledgments: The authors thank: Francesco Giacomin for his activity on data collecting; Enrico De Lillo and Giuseppe Bari of Department of Soil, Plant and Food Sciences, University of Bari 'Aldo Moro' for the concession of microscope and macro photography equipment. This paper has been awarded (ex-aequo) as the Best Paper Awards presented by a PhD student or a recently graduated PhD fellow, at the XIII Italian National Congress on Biodiversity "Biodiversità 2021", 7-9 September 2021, Foggia (Italy). 
Conflicts of Interest: The authors declare no conflict of interest. The funders had no role in the design of the study; in the collection, analyses, or interpretation of data; in the writing of the manuscript, or in the decision to publish the results.

\section{References}

1. Elia, A.; Santamaria, P. Biodiversity in vegetable crops: A heritage to save. The case of the Puglia region. Ital. J. Agron. 2013, 8, e4. [CrossRef]

2. Raggi, L.; Caproni, L.; Negri, V. Landrace added value and accessibility in Europe: What a collection of case studies tells us. Biodiversity and Conservation. Biodivers. Conserv. 2021, 30, 1031-1048. [CrossRef]

3. Renna, M.; Montesano, F.F.; Signore, A.; Gonnella, M.; Santamaria, P. Biodiverso: A case study of integrated project to preserve the biodiversity of vegetable crops in Puglia (southern Italy). Agriculture 2018, 8, 128. [CrossRef]

4. Renna, M.; Signore, A.; Paradiso, V.M.; Santamaria, P. Faba greens, globe Artichoke's offshoots, crenate broomrape and summer squash greens: Unconventional vegetables of Puglia (Southern Italy) with good quality traits. Front. Plant Sci. 2018, 9, 378. [CrossRef]

5. Signore, A.; Renna, M.; Santamaria, P. Agrobiodiversity of Vegetable Crops: Aspect, Needs, and Future Perspectives. In Annual Plant Reviews Online; John Wiley \& Sons, Ltd.: Hoboken, NJ, USA, 2019. [CrossRef]

6. Pavan, S.; Marcotrigiano, A.R.; Ciani, E.; Mazzeo, R.; Zonno, V.; Ruggieri, V.; Lotti, C.; Ricciardi, L. Genotyping-by-sequencing of a melon (Cucumis melo L.) germplasm collection from a secondary center of diversity highlights patterns of genetic variation and genomic features of different gene pools. BMC Genom. 2017, 18, 59. [CrossRef]

7. Renna, M.; D'Imperio, M.; Gonnella, M.; Parente, A.; Santamaria, P.; Serio, F. Barattiere: An italian local variety of Cucumis melo L. with quality traits between melon and cucumber. Plants 2020, 9, 578. [CrossRef] [PubMed]

8. Conversa, G.; Gonnella, M.; Santamaria, P.; Bianco, V.V. Caratterizzazione e valorizzazione di due tipici ortaggi pugliesi: Carosello e barattiere. Colt. Protette 2005, 34, 4-13.

9. Parente, A.; Buttaro, D.; Conversa, G.; Serio, F.; Santamaria, P. Confronto tra sistemi di coltivazione di carosello e barattiere in serra I. Aspetti produttivi. Colt. Protette 2005, 34, 19-27.

10. Serio, F.; Florio, G.; Parente, A.; Santamaria, P. Confronto tra sistem di coltivazione di carosello e barattiere in serra. II. Aspetti qualitativi. Colt. Protette 2005, 34, 28-35.

11. Padulosi, S.; Hodgkin, T.; Williams, J.T.; Haq, N. Underutilized crops: Trends, challenges and opportunities in the 21st century. In Managing Plant Genetic Diversity. Proceedings of an International Conference, Kuala Lumpur, Malaysia, 12-16 June 2000; CABI: Wallingford, UK, 2002; pp. 323-338.

12. Hammer, K.; Hanelt, P.; Perrino, P. Carosello and the taxonomy of Cucumis melo L. especially of its vegetable races. Die Kult. 1986, 34, 249-259. [CrossRef]

13. Laghetti, G.; Accogli, R.; Hammer, K. Different cucumber melon (Cucumis melo L.) races cultivated in Salento (Italy). Genet. Resour. Crop. Evol. 2008, 55, 619-623. [CrossRef]

14. Ricciardi, L.; De Giovanni, C.; Dell'orco, P.; Marcotrigiano, A.R.; Lotti, C. Phenotypic and genetic characterization of Cucumis melo L. Landraces collected in apulia (Italy) and albania. Acta Hortic. 2003, 623, 95-105. [CrossRef]

15. Janick, J.; Paris, H.S.; Parrish, D.C. The cucurbits of Mediterranean antiquity: Identification of taxa from ancient images and descriptions. Ann. Bot. 2007, 100, 1441-1457. [CrossRef]

16. Paris, H.S.; Janick, J.; Daunay, M.C. Medieval herbal iconography and lexicography of Cucumis (cucumber and melon, Cucurbitaceae) in the Occident, 1300-1458. Ann. Bot. 2011, 108, 471-484. [CrossRef]

17. Paris, H.S.; Amar, Z.; Lev, E. Medieval emergence of sweet melons, Cucumis melo (Cucurbitaceae). Ann. Bot. 2012, 110, 23-33. [CrossRef] [PubMed]

18. Sabato, D.; Esteras, C.; Grillo, O.; Peña-Chocarro, L.; Leida, C.; Ucchesu, M.; Usai, A.; Bacchetta, G.; Picó, B. Molecular and morphological characterisation of the oldest Cucumis melo L. seeds found in the Western Mediterranean Basin. Archaeol. Anthropol. Sci. 2019, 11, 789-810. [CrossRef]

19. Buttaro, D.; Bonasia, A.; Minuto, A.; Serio, F.; Santamaria, P. Effect of silicon in the nutrient solution on the incidence of powdery mildew and quality traits in carosello and barattiere (Cucumis melo L.) grown in a soilless system. J. Hortic. Sci. Biotechnol. 2009, 84, 300-304. [CrossRef]

20. Conte, A.; Scrocco, C.; Brescia, I.; Del Nobile, M.A. Different packaging strategies for fresh-cut "barattiere" melon cultivar (Cucumis melo L.). Int. J. Food Sci. Technol. 2009, 44, 1422-1428. [CrossRef]

21. Murgese, P.; Santamaria, P.; Leoni, B.; Crecchio, C. Ameliorative Effects of PGPB on Yield, Physiological Parameters, and Nutrient Transporter Genes Expression in Barattiere (Cucumis melo L.). J. Soil Sci. Plant. Nutr. 2020, 20, 784-793. [CrossRef]

22. Renna, M.; Signore, A.; Lasorella, C.; Santamaria, P.; Cazzato, E.; Fracchiolla, M. Effects of organic farming practices on yield and quality of "Barattiere", a local cultivar of Cucumis melo L. From Puglia (southern Italy). Acta Hortic. 2020, 1294, 53-60. [CrossRef]

23. Gallo, M.; Ciccarese, A.; Ciccarese, F.; Jaupi, M. New source of resistance to Fusarium-wilt in local germplasm of Cucumis melo. Acta Hortic. 2012, 960, 83-88. [CrossRef]

24. Esteras, C.; Rambla, J.L.; Sánchez, G.; López-Gresa, M.P.; González-Mas, M.C.; Fernández-Trujillo, J.P.; Bellés, J.M.; Granell, A.; Picó, M.B. Fruit flesh volatile and carotenoid profile analysis within the Cucumis melo L. species reveals unexploited variability for future genetic breeding. J. Sci. Food Agric. 2018, 98, 3915-3925. [CrossRef] [PubMed] 
25. Esteras, C.; Rambla, J.L.; Sánchez, G.; Granell, A.; Picó, M.B. Melon genetic resources characterization for rind volatile profile. Agronomy 2020, 10, 1512. [CrossRef]

26. Manchali, S.; Chidambara Murthy, K.N.; Patil, B.S.; Patil, B.S. Nutritional composition and health benefits of various botanical types of melon (Cucumis melo L.). Plants 2021, 10, 1755. [CrossRef] [PubMed]

27. Hoagland, D.R.; Arnon, D.I. The water-culture method for growing plants without soil. Circ. Calif. Agric. Exp. Stn. 1950, $347,32$.

28. International Union for the Protection of New Varieties of Plants (UPOV). Melon (Cucumis melo L.), TG/104/5 Rev.2. Guidelines for the Conduct of Tests for Distinctness, Uniformity and Stability. 2019. Available online: https://www.upov.int/edocs/tgdocs/ en/tg104.pdf (accessed on 27 July 2021).

29. IPGRI. Descriptors for Melon (Cucumis melo L.); International Plant Genetic Resources Institute: Rome, Italy, 2003.

30. Pandey, A.; Ranjan, P.; Ahlawat, S.P.; Bhardwaj, R.; Dhariwal, O.P.; Singh, P.K.; Malav, P.K.; Harish, G.D.; Prabhu, P.; Agrawal, A. Studies on fruit morphology, nutritional and floral diversity in less-known melons (Cucumis melo L.) of India. Genet. Resour. Crop. Evol. 2021, 68, 1453-1470. [CrossRef]

31. Kirkbride, J.H. Biosystematic Monograph of the Genus Cucumis (Cucurbitaceae): Botanical Identification of Cucumbers and Melons; US Department of Agriculture: Boone, NC, USA, 1993.

32. Pitrat, M. Phenotypic diversity in wild and cultivated melons (Cucumis melo). Plant Biotechnol. 2013, 30, 273-278. [CrossRef]

33. Schneider, C.A.; Rasband, W.S.; Eliceiri, K.W. NIH Image to ImageJ: 25 years of image analysis. Nat. Methods 2012, 9, 671-675. [CrossRef]

34. PAM-2500 Portable Chlorophyll Fluorometer-Handbook of Operation. Available online: https://www.walz.com/products / chl_p700/pam-2500/introduction.html (accessed on 20 July 2021).

35. Bonasia, A.; Montesano, F.; Parente, A.; Signore, A.; Santamaria, P. Morfologia e Produzione Di Quattro Popolazioni Di Melone Da Consumo Verde. Colt. Protette 2005, 34, 14-18.

36. Lotti, C.; Albo, M.; Ricciardi, L.; Conversa, G.; Elia, A. Studio della diversità genetica tra ecotipi di carosello e barattiere (Cucumis melo L.). Colt. Protette 2005, 34, 44-46.

37. Bianco, V.V. Carosello (Cucumis melo L.). In Orticoltura; Bianco, V.V., Pimpini, F., Eds.; Patro Ed: Bologna, Italy, $1990 ;$ pp. 517-521. 